\title{
Mouse models of myeloproliferative neoplasms for pre-clinical testing of novel therapeutic agents
}

\author{
Jan Stetka ${ }^{a, b}$, Radek C. Skoda ${ }^{a}$
}

\begin{abstract}
Myeloproliferative neoplasms (MPN), are clonal hematopoietic stem cell (HSC) disorders driven by gain-of-function mutations in JAK2 (JAK2-V617F), CALR or MPL genes. MPN treatment options currently mainly consist of cytoreductive therapy with hydroxyurea and JAK2 inhibitors such as ruxolitinib and fedratinib. Pegylated interferon-alpha can induce complete molecular remission (CMR) in some MPN patients when applied at early stages of disease. The ultimate goal of modern MPN treatment is to develop novel therapies that specifically target mutant HSCs in MPN and consistently induce CMR. Basic research has identified a growing number of candidate drugs with promising effects in vitro. A first step on the way to developing these compounds into drugs approved for treatment of MPN patients often consists of examining the effects in vivo using pre-clinical mouse models of MPN. Here we review the current state of MPN mouse models and the experimental setup for their optimal use in drug testing. In addition to novel compounds, combinatorial therapeutic approaches are often considered for the treatment of MPN. Optimized and validated mouse models can provide an efficient way to rapidly assess and select the most promising combinations and thereby contribute to accelerating the development of novel therapies of MPN.
\end{abstract}

Key words: MPN, myeloproliferative neoplasms, JAK2, mouse model, pre-clinical models, novel therapies

Received: December 14, 2020; Revised: January 7, 2021; Accepted: January 8, 2021; Available online: February 4, 2021 https://doi.org/10.5507/bp.2021.004

() 2021 The Authors; https://creativecommons.org/licenses/by/4.0/

${ }^{a}$ Department of Biomedicine, Experimental Hematology, University Hospital Basel and University of Basel, Basel, Switzerland ${ }^{b}$ Department of Biology, Faculty of Medicine and Dentistry, Palacky University Olomouc, Czech Republic

Corresponding authors: Jan Stetka, e-mail:jan.stetka@unibas.ch and Radek C. Skoda, e-mail: radek.skoda@unibas.ch

\section{INTRODUCTION}

Myeloproliferative neoplasms (MPNs) were proposed in 1951 by William Dameshek to represent "somewhat variable manifestations of proliferative activity of bone marrow cells" and to constitute a group of closely interrelated diseases ${ }^{1}$. Today, three disease entities are summarized under the term "BCR/ABL-negative MPN" (ref., ${ }^{2,3}$ ). Polycythemia vera (PV) is characterized by increased erythropoiesis and is frequently accompanied by thrombocytosis and leukocytosis, while essential thrombocythemia (ET) manifests as augmented megakaryopoiesis with thrombocytosis, but with normal red cell parameters. Primary myelofibrosis (PMF) requires histological proof of reticulin fibrosis and is frequently accompanied by anemia and extramedullary hematopoiesis. The currently used diagnostic criteria for MPN are defined by the World Health Organization (WHO) (ref. $\left.{ }^{2}\right)$. As proposed by Dameshek, MPN subentities are interrelated, as ET can sometimes convert to PV and both ET and PV can progress to myelofibrosis (post ET-MF or post-PV-MF). MPNs have been demonstrated to be clonal diseases of the hematopoietic stem cell (HSCs) driven by acquired gain-of-function mutations in Janus kinase 2 (JAK2), Calreticulin (CALR) and Thrombopoietin receptor (MPL) genes $^{4-10}$. These driver gene mutations in most patients are mutually exclusive. Only a few patients with more than one driver gene mutation have been studied in detail and in these cases each driver gene mutation represented an independent clone $\mathrm{e}^{11,12}$.

$J A K 2-\mathrm{V} 617 \mathrm{~F}$, the most frequent MPN driver mutation, is found in $>95 \%$ of PV patients, and also in approximately one-half of patients with ET or PMF $\left(\right.$ ref. $\left.^{47}\right)$. MPN progenitors and stem cells are hypersensitive to cytokines due to augmented intracellular signaling by the mutant $J A K 2$-V617F (ref. ${ }^{13}$ ). Mutations in CALR and MPL also increase the JAK2/STAT signaling by activating cytokine receptors independently of their cognate ligands ${ }^{14}$. In some MPN patients, driver gene mutations are complemented by additional somatic mutations, most frequently affecting genes involved in epigenetic regulation inflammation, DNA damage response and Ras signaling, that can modify the disease course and contribute to disease initiation and/or progression ${ }^{15}$.

A large number of mouse models have been developed to study MPN pathogenesis and to advance our current understanding of MPN disease initiation and progres$\operatorname{sion}^{16-20}$. These mouse models have been also used to examine the effects of therapeutic agents on MPN disease manifestations. Identification and validation of novel therapeutic agents in pre-clinical models of MPN is an extremely important and valuable step in the development of novel drugs for MPN patients. In this review we discuss the use of different types of mouse models and experimental setups to study candidate drugs for MPN treatment. We also provide examples of modern therapies that have been first tested in MPN mouse models. 
Table 1. MPN mouse models with $J A K 2-\mathrm{V} 617 \mathrm{~F}$.

\begin{tabular}{lllllc}
\hline JAK2-origin & Type of model & Promoter & Phenotype & Background & Ref. \\
\hline Mouse & retroviral & viral LTR & PV & C57BL/6 & 6 \\
Mouse & retroviral & viral LTR & PV & BALB/c and C57BL/6 & 21 \\
Mouse & retroviral & viral LTR & PV & BALB/c and C57BL/6 & 22 \\
Mouse & retroviral & viral LTR & PV & C57BL/6 & 23 \\
Mouse & retroviral & viral LTR & PV & BALB/c & 24 \\
Human & oocyte injection & Vav & PV & C57BL/6/DBA/2 & 25 \\
Mouse & oocyte injection & H-2Kb & ET/PV & C57BL/6/DBA/2 & 26 \\
Human & BAC oocyte injection & hJAK2 & ET/PV & C57BL/6 & 27 \\
Human & oocyte injection & TetOCMV & +ET/ ơPV & C57BL/6 & 29 \\
Mouse & knock-in & mJak2 & PV & 129Sv/C57BL/6 & 30 \\
Human & knock-in & mJak2 & ET & 129Sv/C57BL/6 & 33 \\
Mouse & knock-in & mJak2 & PV & 129Sv/C57BL/6 & 31 \\
Mouse & knock-in & mJak2 & PV & 129Sv/C57BL/6 & 32 \\
\hline
\end{tabular}

\section{Mouse models of MPN}

Retroviral transduction models were first used to characterize the $J A K 2-\mathrm{V} 617 \mathrm{~F}$ signaling and to confirm its effects on MPN phenotype in vivo (summarized in Table 1) (ref., ${ }^{61-24}$ ). Bone marrow cells were transduced with retroviral vectors carrying cDNA encoding $J A K 2-\mathrm{V} 617 \mathrm{~F}$ and transplanted into syngeneic recipient mice, resulting in PV phenotype that in most cases rapidly progressed to myelofibrosis. Since retroviral transduction required HSCs to divide in culture, some of the retroviral models exhausted prematurely after a few months and were unable to engraft in secondary transplantations ${ }^{24}$.

Transgenic models of MPN (summarized in Table 1) provide a more robust and reproducible system for preclinical drug testing in vivo. The first transgenic models used a cDNA encoding mouse or human JAK2-V617F that was placed under the control of a ubiquitous or tissue specific promoter and injected into mouse oocyte ${ }^{25,26}$. A more advanced transgenic model used a bacterial artificial chromosome (BAC) containing a large part of the human $J A K 2$ gene (exons 1-12). The V617F mutation was introduced as a cDNA covering JAK2 exons 13-25 that were placed in reverse orientation and flanked by antiparallel loxP sites to make expression of JAK2-V617F conditional ${ }^{27}$. When activated by Cre-recombinase, these BAC transgenic mice express the human JAK2-V617F under the control of the human $J A K 2$ promoter and manifested with ET or PV phenotypes, with late transformation to post-MPN myelofibrosis recapitulating the full MPN pathophysiology observed in patients. When constitutive VavCre was used activate the JAK2-V617F transgene, ET phenotype was observed and was associated with lower $J A K 2-\mathrm{V} 617 \mathrm{~F}$ expression levels in bone marrow, whereas PV phenotype resulted when conditional MxCre or SclCre was used activate the transgene, leading to higher JAK2-V617F expression ${ }^{27,28}$. Recently, transgenic mice expressing Jak2-V617F under the tetracyclin dependent SCL-tTA-2S tet-off system were generated ${ }^{29}$. Using this system, the authors showed that turning on Jak2-V617F expression resulted in MPN phenotype and turning off Jak2-V617F reversed the phenotypic features, indicating that mutant selective JAK2 inhibitors should profoundly disable the JAK2-V617F MPN clone.
Later several transgenic models were generated that introduced the V617F mutation into the endogenous mouse Jak2 locus as a conditional knock-in ${ }^{30-32}$. These mice express the mouse Jak2-V617F and display a strong PV phenotype with moderate thrombocytosis and leukocytosis. In contrast, a knock-in model where exon 2 of mouse Jak2 was replaced with a cDNA for the human JAK2-V617F presented with a very mild ET-like phenotype, but when the knock-in allele was intercrossed to homozygosity, the mice displayed a strong PV phenotype ${ }^{33,34}$.

Recently, also mouse models for MPN driven by CALR mutations have been generated ${ }^{35-39}$. Most of the models used the CALRdel52 mutation, but recently also mice expressing the CALRins 5 mutation have been described ${ }^{40}$. Both CALRdel52 and CALRins5 mice developed ET phenotype with thrombocytosis, leukocytosis and variable degree of fibrosis similar to MPN patients with CALR mutations. So far only a retroviral mouse model has been established for the MPL-W515L mutation found in patients with ET or PMF (ref. ${ }^{41-43}$ ). These mice develop a very rapid MPN-like disease with severe myelofibrosis, and early lethality. The phenotype is likely due to the increased and in part ectopic expression of $M P L-\mathrm{W} 515 \mathrm{~L}$ driven by the retroviral LTR.

Overall, these mouse mutants proved that expression of the JAK2, CALR or MPL mutants can alone cause MPN phenotype in mice and established them as driver gene mutations. Since about half of MPN patients carry additional somatic mutations that can modify the course of the disease ${ }^{44}$, the MPN mouse models have then been crossed with mice carrying mutations in such modifier genes. The double mutant mice drive expansion of LT-HSC compartment by increasing their self-renewal, stemness and repopulation capacity, leading to clonal dominance. In most cases these models faithfully recapitulated the acceleration and modifications of the phenotypes that were also observed in patients carrying the same mutations. This was observed in particular with double mutant mouse models with mutations in epigenetic regulator genes, such as Ezh2 (ref. ${ }^{45-47}$ ), Tet2 (ref. ${ }^{48,49}$ ), Dnmt3a $\left(\right.$ ref. $\left.^{50}\right)$, and Asxll (ref..$^{51}$ ), which are also among the most frequently found additional mutations in patients with MPN. As an alternative to intercrossing genetically 
engineered mouse models, recently techniques using clustered regularly interspaced short palindromic repeats (CRISPR) with CRISPR-associated protein 9 (Cas9) were applied to target specific genomic loci for loss of function mutations in vivo. CRISPR/Cas9 techniques are especially useful in modeling complex genotype combinations, exemplified by a study, in which mutations in up to five genes (Dnmt3a, Runx1, Nf1, Tet2, and Ezh2) were introduced in a single HSC (ref. ${ }^{52}$ ). CRISPR/Cas9 in vivo system was also used to generate MPN mouse models ${ }^{39,50,53}$ that may replace complicated breeding's for studies examining the contribution of multiple loci.

Finally, xenotransplantation models using patientderived xenografts (PDX) into immuno-compromised recipient mice represent an attractive complement to genetic mouse models. PDX models allow studying human primary cancer and leukemia cells in vivo and they have been used for pre-clinical drug testing e.g. in leukemia ${ }^{54}$ and solid cancers ${ }^{55}$. They provide the advantage that primary human cells can be studied. However, PDX models for MPN so far showed limited multilineage engraftment and self-renewal capacity, with large patient to patient variability making PDX difficult to use for drug testing compared to standard MPN mouse models ${ }^{56,57}$. Injection of patient-derived CD34 ${ }^{+}$HSCs into mice that were implanted with ossicles derived from human mesenchymal stem cells showed only transient improvement in engraftment ${ }^{58}$. More recently, humanized $\mathrm{Rag} 2^{-/} \mathrm{I} 12 \mathrm{r}^{-/}$immunodeficient mice that are engineered to express a number of non-cross-reactive human cytokines and growth factors became available ${ }^{59}$. One of these strains, the "MISTRG" mice, express human macrophage colony-stimulating factor (M-CSF), interleukin-3 (IL-3), granulocyte-macrophage colony-stimulating factor (GM-CSF), signal regulatory protein a $(\operatorname{SIRP} \alpha)$. The interaction between human CD47 on the PDX graft and human SIRP $\alpha$ on mouse macrophages provides a "don't eat me" signal that favors the expansion of human hematopoiesis in mice ${ }^{60}$.
MISTRG mice were recently shown to improve engraftment of MPN PDX samples ${ }^{61}$.

\section{MPN mouse models for pre-clinical testing of new therapeutic agents}

Original studies to test the compounds imatinib, dasatinib, AG490, and TG101348 used retroviral models expressing $J A K 2-\mathrm{V} 617 \mathrm{~F}$ (ref. ${ }^{22,62}$ ). These studies provided first in vivo proof-of-principle that JAK2 inhibitors have therapeutic effects on MPN (Fig. 1). However, the retroviral models are not optimal for drug studies. The main disadvantages include the unphysiologically high expression levels of the mutant JAK2-V617F driven by the retroviral LTR promoter ( $>10$-fold higher that endogenous mouse Jak2), variable severity of the phenotype dependent on the retroviral titer and absence of thrombocytosis. However, the MPL-W515L retroviral model is still frequently used for drug studies because these mice rapidly develop severe myelofibrosis ${ }^{63,64}$.

Early studies in primary transgenic mice monitored normalization of blood counts and splenomegaly, but did not follow changes in the mutant allele burden ${ }^{26,32}$. To expand the size of the cohort that allowed testing of multiple drugs, bone marrow transplantations into irradiated recipients mice were introduced ${ }^{32}$. At the same time competitive transplantations of mixtures of JAK2-V617F and wildtype bone marrow cells into recipient mice were performed to mimic the situation in MPN patients, where $J A K 2$-mutant and wildtype hematopoietic cells co-exist. Furthermore, to follow the $J A K 2$-mutant cells, a polymorphism in the Ptprc gene that encodes CD45, also called leukocyte antigen 5 (Ly5) was used ${ }^{65}$. C57BL/6 mice, including most $J A K 2-\mathrm{V} 617 \mathrm{~F}$ transgenic models express the CD45.2 variant. Congenic C57BL/6 mice that express CD 45.1 were generated by backcrossing and used as donors of the wildtype bone marrow competitor cells and also as recipients (Fig. 2). The first such competitive transplantations were used to determine the effects of

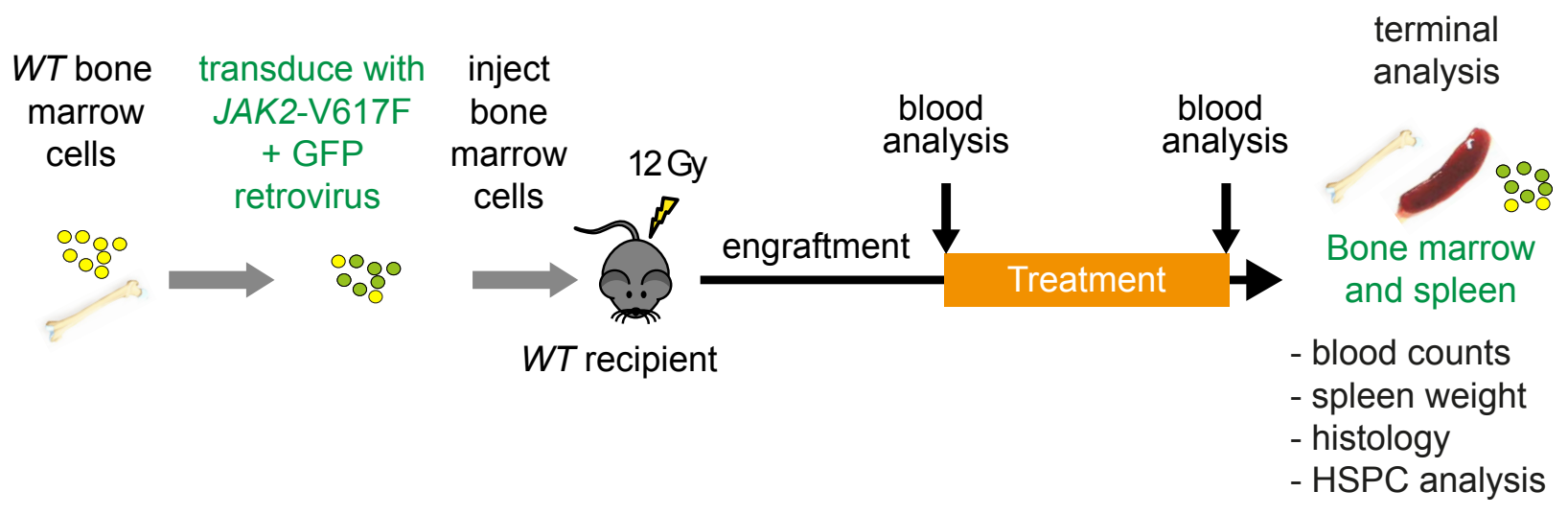

Fig. 1. Experimental setup for candidate drug testing in retroviral MPN mouse models. Wildtype (WT) bone marrow cells are transduced with murine retrovirus harboring the mutant $J A K 2-\mathrm{V} 617 \mathrm{~F}$ allele. Transduced bone marrow cells are selected based on expression of GFP reporter and transplanted via tail vein injection into the lethally irradiated syngeneic recipient mice. After engraftment, the recipient mice are allowed to develop MPN phenotype and are randomized into treatment or vehicle control groups. Complete blood counts and GFP chimerism are determined in peripheral blood at defined timepoints. At the end of the treatment the mice are sacrificed and terminal analysis of cells and organs is performed. 


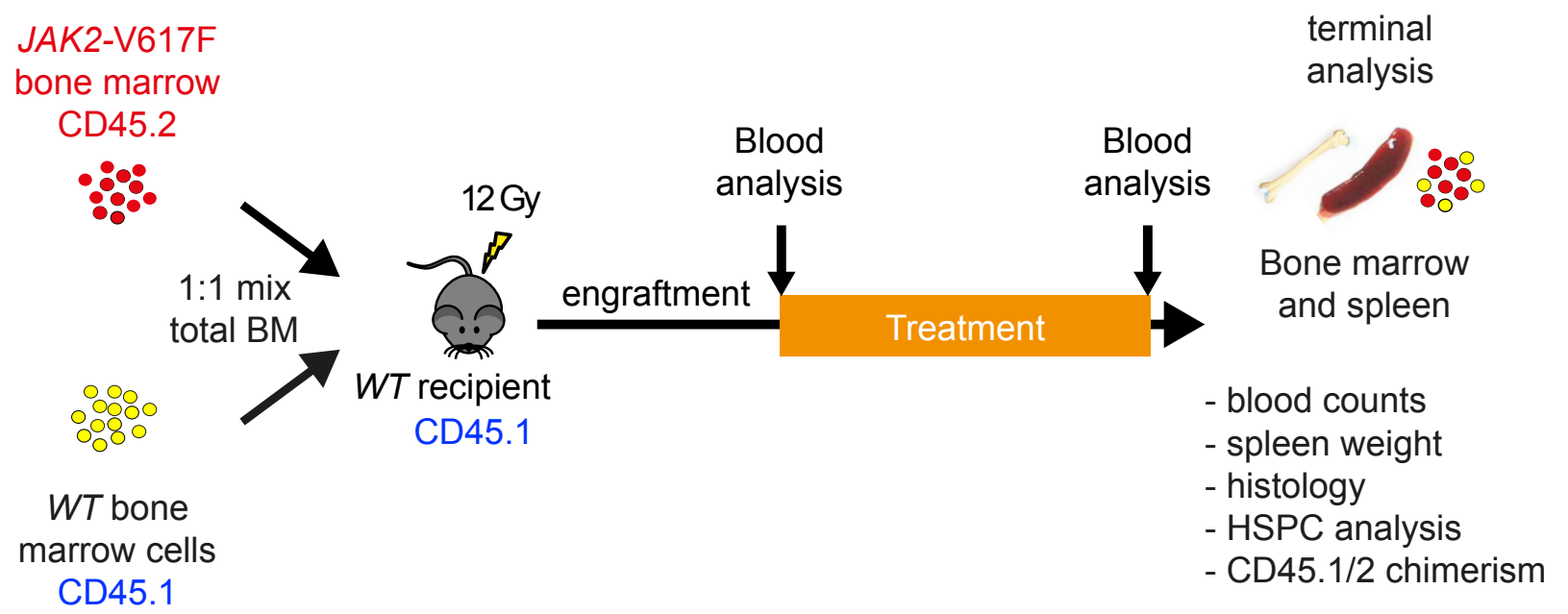

Fig. 2. Experimental setup for candidate drug testing in pre-clinical MPN mouse models with CD45.1/2 reporter gene. Bone marrow (BM) cells expressing $J A K 2-\mathrm{V}_{617 \mathrm{~F}^{+}}$and $\mathrm{CD} 45.2$ (red) are mixed with wildtype (WT) competitor cells expressing CD45.1 (yellow) and injected into lethally irradiated CD45.1 recipient mice (blue). After engraftment, the recipient mice are allowed to develop MPN phenotype and are randomized into treatment or vehicle control groups. Complete blood counts and CD45.1/2 chimerism are determined in peripheral blood at defined timepoints. At the end of the treatment the mice are sacrificed, and terminal analysis of cells and organs is performed.

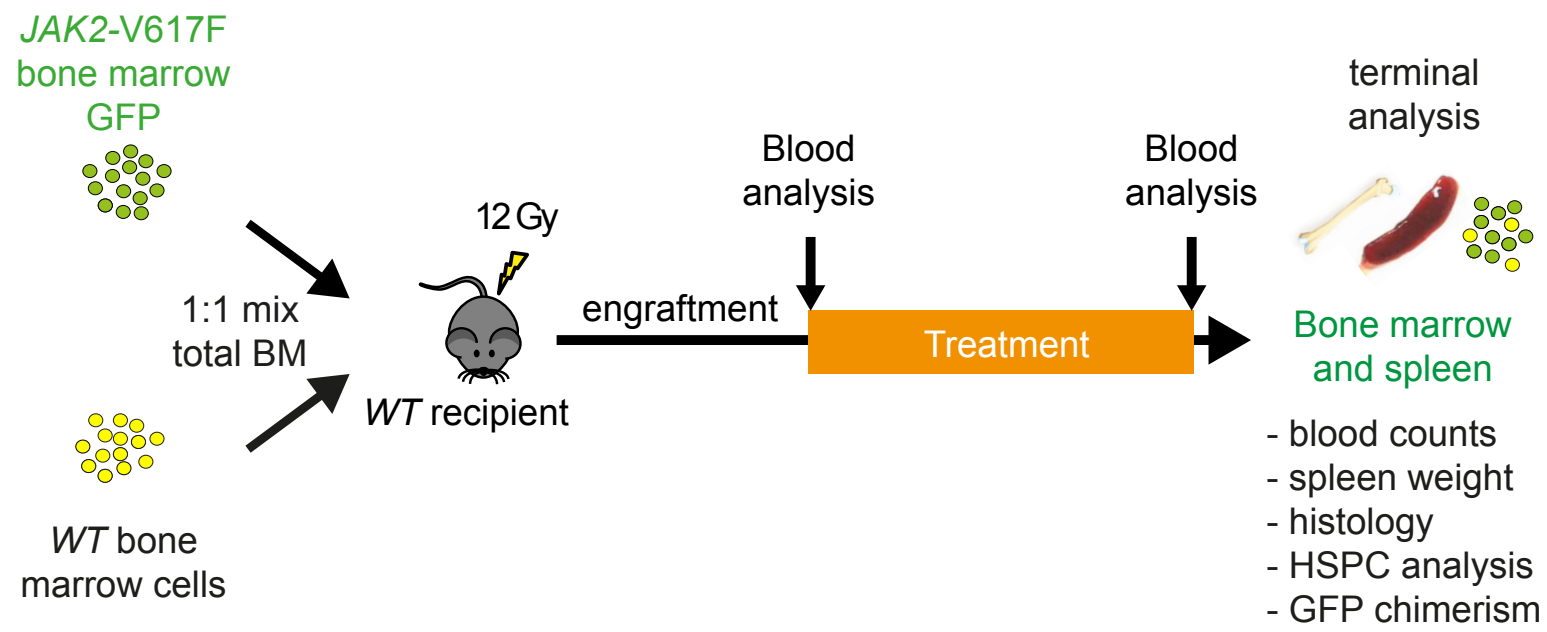

Fig. 3. Experimental setup for candidate drug testing in pre-clinical MPN mouse models with GFP reporter gene. Bone marrow (BM) cells co-expressing $J A K 2-V 617 \mathrm{~F}^{+}$and GFP in all hematopoietic cells (green) are mixed with wildtype (WT) competitor cells (yellow) and injected into lethally irradiated syngeneic recipient mice. After engraftment, the recipient mice are allowed to develop MPN phenotype and are randomized into treatment or vehicle control groups. Complete blood counts and GFP chimerism are determined in peripheral blood at defined timepoints. At the end of the treatment the mice are sacrificed, and terminal analysis of cells and organs is performed.

vorinostat, a small-molecule inhibitor of histone deacetylation, on Jak2-V617F allele burden ${ }^{66}$. For this purpose, bone marrow from inducible Jak2-V617F knock-in mice (CD45.2) were mixed at a ratio of 3:1 with the BM from wildtype (CD45.1) mice and injected into lethally irradiated CD $45.1^{+}$recipient animals. Similar approach was used in studies of combined JAK2 and Bcl-2/Bcl-xL inhibition by TG101209 and ABT-737 inhibitors ${ }^{67}$, interferon- $\alpha$ treatment of Jak2-V617F knock-in mice ${ }^{68-70}$ and a novel type II JAK2 inhibitor ${ }^{63}$. A disadvantage of the CD45.1/2 reporter lies in the absence of CD45 antigen on a surface of erythrocytes and platelets, two major lineages that define MPN disease phenotype. Therefore, CD45.1/2 does not allow following the $J A K 2$-mutant chimerism in peripheral blood Ter $119^{+}$red cells and $\mathrm{CD} 61^{+}$platelets. In addition, recent studies show that despite backcrossing into C57BL/6, a small amount of the original SJL mouse background, from which CD45.1 was derived, is retained in C57BL/6 CD45.1 mice from some vendor sources ${ }^{71}$. This includes regions encompassing genes of immunological importance, explaining previously observed problems of hematopoietic stem cell reconstitution being less efficient from C57BL/6 CD45.1, compared to C57BL/6 CD45.2 mice $^{72-74}$. A new congenic CD45.1 ${ }^{\text {STEM }}$ knock-in 
line that carries a single point mutation in Ptprc was generated directly in C57BL/6 background ${ }^{75}$. These CD45.1 STEM $^{\text {ST }}$ knock-in mice should now overcome this problem.

A more complete labeling of all $J A K 2$-mutant cells was achieved using mice that express the green fluorescent protein (GFP) reporter driven by a ubiquitous $U B C$ promoter in all hematopoietic cells ${ }^{76}$. Crossing $U B C$-GFP mice with $J A K 2-\mathrm{V} 617 \mathrm{~F}$ mice resulted in double transgenic mice that co-express $J A K 2$-V617F and GFP in all hematopoietic cells, including peripheral blood leukocytes, erythrocytes and platelets and represent an improved system for drug studies (Fig. 3). Competitive transplantations with bone marrow cells from such double transgenic mice were first used to compare the efficacy of hydroxyurea and ruxolitinib ${ }^{28}$. The GFP reporter system combined with transgenic models of $J A K 2-\mathrm{V} 617 \mathrm{~F}$ is reliable and can be applied also for testing combinations of drug treatment. Recently, this approach was used to show synergism between interferon- $\alpha$ and arsenic $^{77}$.

Since $1 \times 10^{6}$ bone marrow cells from $J A K 2$-mutant mice contain about 60-100 HSCs, competitive transplantations at 1:1 ratio with wildtype competitor cells results in MPN that is essentially polyclonal. Drugs that decrease $J A K 2$-mutant allele burden may have to overcome potential escape mechanisms though selection of $J A K 2$-mutant HSCs that are resistant to the treatment. Therefore, competitive transplantations at higher dilutions of the $J A K 2$ mutant cells, e.g. 1:20, could be a better system to test the ability of drugs to selectively target the mutant JAK2 and decrease the mutant allele burden. In principle, recipient mice reconstituted from a single $J A K 2$-V617F mutant HSC can be generated by transplantation of single HSCs or by limiting dilution of transplanted bone marrow cells ${ }^{20}$. However, such an approach would require transplanting a large number of recipients, since only about $30 \%$ of recipients at limiting dilution engraft and display MPN phenotype and would therefore not be practical for routine use.

\section{CONCLUSIONS}

Transgenic MPN mouse models have been developed for JAK2-V617F, JAK2 exon 12 mutation and CALR mutations. The optimal experimental setup for candidate drug testing in pre-clinical MPN mouse models should include reporters expressed in all blood cells, e.g. $U B C$-GFP, that allows tracking the MPN cells in all organs including peripheral blood. Competitive bone marrow transplantations allow expanding the cohort for testing multiple compounds and combinations of drugs. Presence of wildtype HSCs, derived from the wildtype competitor bone marrow, can maintain hematopoiesis when MPN HSCs are effectively targeted by new therapeutic approaches. Transgenic mouse models with reversible on-off $J A K 2$ V617F expression ${ }^{29}$, could serve as a the ideal positive controls for drugs that are selective for the mutant JAK2 proteins.

Mice with more complex mutation genotypes, e.g. combinations of $J A K 2-\mathrm{V} 617 \mathrm{~F}$ with mutations in Tet2, Ezh2, Dnmt3a or Asxll that are found in patients with
MPN can also be used as bone marrow donors, which will allow testing drugs in these more complex MPN models. The CRISPR/Cas9 technology could further facilitate and speed up the generation of complex genotypes for such studies. Retroviral models, such as MPL-W515L can also remain useful in specific setting, e.g. to study rapid progression to myelofibrosis without the need to wait several months for myelofibrosis to develop, as is the case with the transgenic models for $J A K 2-\mathrm{V} 617 \mathrm{~F}$.

The PDX models using improved recipient mice such as MISTERG (ref. ${ }^{61}$ ) could become the next step in preclinical MPN mouse models for drug testing, if some of the main hurdles can be overcome. These include the difficulties obtaining a large cohort of recipient mice reconstituted from the same MPN patient donor, variability of phenotypes between mice engrafted with cells from the same MPN donor and inter-individual differences in MPN phenotypes between different MPN donors. Overall, the MPN field already now has excellent pre-clinical in vivo models for drug testing, which can contribute to accelerating the development of novel therapies of MPN.

\section{Search strategy and selection criteria}

Our research strategy was aimed at evaluating studies on the mouse models of myeloproliferative neoplasms used for pre-clinical testing of novel therapeutic agents. Data for this article were identified by searches of PubMed and Google Scholar databases and references from relevant articles using the terms "MPN", "myeloproliferative neoplasms", "JAK2", "mouse models", "transplantation", "novel therapies". All searches were up to date as of December 2020. Only articles published in English were included, abstracts and reports from meetings were not included. We gave preference to publications from the past 10 years.

Acknowledgement: We thank members of the laboratory for helpful discussions and critical reading of our manuscript. Grant support: JS was partially supported by the Czech Science Foundation grant 17-05988S and Palacký University Mobility project no. CZ.02.2.69/0.0/0.0/16_0 27/0008482. RCS was supported by grants from the Swiss National Science Foundation (31003A_179490), and the Swiss Cancer League (KFS-4462-02-2018)

Author contributions: JS, RCS: reviewed the literature, wrote the manuscript, and contributed to its revision.

Conflict of interest statement: The authors state that there are no conflicts of interest regarding the publication of this article.

\section{REFERENCES}

1. Dameshek W. Some speculations on the myeloproliferative syndromes. Blood 1951;6(4):372-5.

2. Arber DA, Orazi A, Hasserjian R, Thiele J, Borowitz MJ, Le Beau MM, Bloomfield CD, Cazzola M, Vardiman JW. The 2016 revision to the World Health Organization classification of myeloid neoplasms and acute leukemia. Blood 2016;127(20):2391-405.

3. Levine RL, Gilliland DG. Myeloproliferative disorders. Blood 2008;112(6):2190-8. 
4. Kralovics R, Passamonti F, Buser AS, Teo S-S, Tiedt R, Passweg JR, Tichelli A, Cazzola M, Skoda RC. A gain-of-function mutation of JAK2 in myeloproliferative disorders. N Engl J Med 2005;352(17):1779-90.

5. Levine RL, Wadleigh M, Cools J, Ebert BL, Wernig G, Huntly BJP, Boggon TJ, Wlodarska I, Clark JJ, Moore S, Adelsperger J, Koo S, Lee JC, Gabriel S, Mercher T, D'Andrea A, Fröhling S, Döhner K, Marynen P, Vandenberghe P, Mesa RA, Tefferi A, Griffin JD, Eck MJ, Sellers WR, Meyerson M, Golub TR, Lee SJ, Gilliland DG. Activating mutation in the tyrosine kinase JAK2 in polycythemia vera, essential thrombocythemia, and myeloid metaplasia with myelofibrosis. Cancer Cell 2005;7(4):38-97.

6. James C, Ugo V, Le Couédic J-P, Staerk J, Delhommeau F, Lacout C, Garçon L, Raslova H, Berger R, Bennaceur-Griscelli A, Villeval JL, Constantinescu SN, Casadevall N, Vainchenker W. A unique clonal JAK2 mutation leading to constitutive signalling causes polycythaemia vera. Nature 2005;434(7037):1144-8.

7. Baxter EJ, Scott LM, Campbell PJ, East C, Fourouclas N, Swanton S, Vassiliou GS, Bench AJ, Boyd EM, Curtin N, Scott MA, Erber WN, Green AR, Cancer Genome Project. Acquired mutation of the tyrosine kinase JAK2 in human myeloproliferative disorders. Lancet 2005;365(9464):1054-61.

8. Klampfl $\mathrm{T}$, Gisslinger $\mathrm{H}$, Harutyunyan AS, Nivarthi $\mathrm{H}$, Rumi E, Milosevic JD, Them NCC, Berg T, Gisslinger B, Pietra D, Chen D, Vladimer GI, Bagienski K, Milanesi C, Casetti IC, Sant'Antonio E, Ferretti V, Elena C, Schischlik F, Cleary C, Six M, Schalling M, Schönegger A, Bock C, Malcovati L, Pascutto C, Superti-Furga G, Cazzola M, Kralovics R. Somatic mutations of calreticulin in myeloproliferative neoplasms. N Engl J Med 2013;369(25):2379-90.

9. Nangalia J, Massie CE, Baxter EJ, Nice FL, Gundem G, Wedge DC, Avezov E, Li J, Kollmann K, Kent DG, Aziz A, Godfrey AL, Hinton J, Martincorena I, Van Loo P, Jones AV, Guglielmelli P, Tarpey P, Harding HP, Fitzpatrick JD, Goudie CT, Ortmann CA, Loughran SJ, Raine K, Jones DR, Butler AP, Teague JW, O'Meara S, McLaren S, Bianchi M, Silber Y, Dimitropoulou D, Bloxham D, Mudie L, Maddison M Robinson B, Keohane C, Maclean C, Hill K, Orchard K, Tauro S, Du M-Q, Greaves M, Bowen D, Huntly BJP, Harrison CN, Cross NCP, Ron D, Vannucchi AM, Papaemmanuil E, Campbell PJ, Green AR. Somatic CALR Mutations in Myeloproliferative Neoplasms with Nonmutated JAK2. N Engl J Med 2013;369(25):2391-405.

10. Pikman Y, Lee BH, Mercher T, McDowell E, Ebert BL, Gozo M, Cuker A, Wernig G, Moore S, Galinsky I, DeAngelo DJ, Clark JJ, Lee SJ, Golub TR, Wadleigh M, Gilliland DG, Levine RL. MPLW515L is a novel somatic activating mutation in myelofibrosis with myeloid metaplasia. PLoS Med 2006;3(7):e270.

11. Lundberg P, Karow A, Nienhold R, Looser R, Hao-Shen H, Nissen I, Girsberger S, Lehmann T, Passweg J, Stern M, Beisel C, Kralovics R, Skoda RC. Clonal evolution and clinical correlates of somatic mutations in myeloproliferative neoplasms. Blood 2014;123(14):2220-8.

12. Beer PA, Jones AV, Bench AJ, Goday-Fernandez A, Boyd EM, Vaghela KJ, Erber WN, Odeh B, Wright C, McMullin MF, Cullis J, Huntly BJP, Harrison CN, Cross NCP, Green AR. Clonal diversity in the myeloproliferative neoplasms: independent origins of genetically distinct clones. Br J Haematol 2009;144(6):904-8.

13. Wilmes $S$, Hafer M, Vuorio J, Tucker JA, Winkelmann $H$, Löchte $S$, Stanly TA, Pulgar Prieto KD, Poojari C, Sharma V, Richter CP, Kurre R, Hubbard SR, Garcia KC, Moraga I, Vattulainen I, Hitchcock IS, Piehler J. Mechanism of homodimeric cytokine receptor activation and dysregulation by oncogenic mutations. Science 2020;367(6478):643-52.

14. Skoda RC, Duek A, Grisouard J. Pathogenesis of myeloproliferative neoplasms. Exp Hematol 2015;43(8):599-608.

15. Vainchenker W, Kralovics R. Genetic basis and molecular pathophysiology of classical myeloproliferative neoplasms. Blood 2017;129(6):667-79.

16. Li J, Kent DG, Chen E, Green AR. Mouse models of myeloproliferative neoplasms: JAK of all grades. Dis Model Mech 2011;4(3):311-7.

17. Dunbar A, Nazir A, Levine R. Overview of Transgenic Mouse Models of Myeloproliferative Neoplasms (MPNs). Curr Protoc Pharmacol 2017;77:14.40.1-19.

18. Mullally A, Lane SW, Brumme K, Ebert BL. Myeloproliferative Neoplasm Animal Models. Hematol Oncol Clin North Am 2012;26(5):1065-81.

19. Lanikova L, Babosova O, Prchal JT. Experimental Modeling of Myeloproliferative Neoplasms. Genes (Basel) 2019;10(10):813.

20. Lundberg P, Takizawa H, Kubovcakova L, Guo G, Hao-Shen H, Dirnhofer S, Orkin SH, Manz MG, Skoda RC. Myeloproliferative neo- plasms can be initiated from a single hematopoietic stem cell expressing JAK2-V617F. J Exp Med 2014;211(11):2213-30.

21. Wernig G, Mercher T, Okabe R, Levine RL, Lee BH, Gilliland DG. Expression of Jak2 $617 \mathrm{~F}$ causes a polycythemia vera-like disease with associated myelofibrosis in a murine bone marrow transplant model. Blood 2006;107(11):4274-81.

22. Zaleskas VM, Krause DS, Lazarides K, Patel N, Hu Y, Li S, Van Etten RA. Molecular pathogenesis and therapy of polycythemia induced in mice by JAK2 V617F. PLoS One 2006;1:e18.

23. Lacout C, Pisani DF, Tulliez M, Gachelin FM, Vainchenker W, Villeval J-L. JAK2V617F expression in murine hematopoietic cells leads to MPD mimicking human PV with secondary myelofibrosis. Blood 2006;108(5):1652-60.

24. Bumm TGP, Elsea C, Corbin AS, Loriaux M, Sherbenou D, Wood L, Deininger J, Silver RT, Druker BJ, Deininger MWN. Characterization of murine JAK2V617F-positive myeloproliferative disease. Cancer Res 2006;66(23):11156-65.

25. Xing S, Wanting TH, Zhao W, Ma J, Wang S, Xu X, Li Q, Fu X, Xu M, Zhao ZJ. Transgenic expression of JAK2V617F causes myeloproliferative disorders in mice. Blood 2008;111(10):5109-17.

26. Shide K, Shimoda HK, Kumano T, Karube K, Kameda T, Takenaka K, Oku S, Abe H, Katayose KS, Kubuki Y, Kusumoto K, Hasuike S, Tahara Y, Nagata K, Matsuda T, Ohshima K, Harada M, Shimoda K. Development of ET, primary myelofibrosis and PV in mice expressing JAK2 V617F. Leukemia 2008;22(1):87-95.

27. Tiedt R, Hao-Shen H, Sobas MA, Looser R, Dirnhofer S, Schwaller J, Skoda RC. Ratio of mutant JAK2-V617F to wild-type Jak2 determines the MPD phenotypes in transgenic mice. Blood 2008;111 (8):3931-40.

28. Kubovcakova L, Lundberg $P$, Grisouard J, Hao-Shen $H$, Romanet $V$, Andraos R, Murakami M, Dirnhofer S, Wagner K-U, Radimerski T, Skoda RC. Differential effects of hydroxyurea and INC424 on mutant allele burden and myeloproliferative phenotype in a JAK2-V617F polycythemia vera mouse model. Blood 2013;121(7):1188-99.

29. Chapeau EA, Mandon E, Gill J, Romanet V, Ebel N, Powajbo V Andraos-Rey R, Qian Z, Kininis M, Zumstein-Mecker S, Ito M, Hynes $\mathrm{NE}$, Tiedt R, Hofmann F, Eshkind L, Bockamp E, Kinzel B, Mueller M, Murakami M, Baffert F, Radimerski T. A conditional inducible JAK2V617F transgenic mouse model reveals myeloproliferative disease that is reversible upon switching off transgene expression. PLoS One 2019;14(10):e0221635.

30. Akada H, Yan D, Zou H, Fiering S, Hutchison RE, Mohi MG. Conditional expression of heterozygous or homozygous Jak2V617F from its endogenous promoter induces a polycythemia vera-like disease. Blood 2010;115(17):3589-97.

31. Marty C, Lacout C, Martin A, Hasan S, Jacquot S, Birling M-C, Vainchenker W, Villeval J-L. Myeloproliferative neoplasm induced by constitutive expression of JAK2V617F in knock-in mice. Blood 2010;116(5):783-7.

32. Mullally A, Lane SW, Ball B, Megerdichian C, Okabe R, Al-Shahrour F, Paktinat M, Haydu JE, Housman E, Lord AM, Wernig G, Kharas MG, Mercher T, Kutok JL, Gilliland DG, Ebert BL. Physiological Jak2V617F expression causes a lethal myeloproliferative neoplasm with differential effects on hematopoietic stem and progenitor cells. Cancer Cell 2010;17(6):584-96.

33. Li J, Spensberger D, Ahn JS, Anand S, Beer PA, Ghevaert C, Chen E, Forrai A, Scott LM, Ferreira R, Campbell PJ, Watson SP, Liu P, Erber WN, Huntly BJP, Ottersbach K, Green AR. JAK2 V617F impairs hematopoietic stem cell function in a conditional knock-in mouse model of JAK2 V617F-positive essential thrombocythemia. Blood 2010;116(9):1528-38.

34. Li J, Kent DG, Godfrey AL, Manning H, Nangalia J, Aziz A, Chen E, Saeb-Parsy K, Fink J, Sneade R, Hamilton TL, Pask DC, Silber Y, Zhao X, Ghevaert C, Liu P, Green AR. JAK2V617F homozygosity drives a phenotypic switch in myeloproliferative neoplasms, but is insufficient to sustain disease. Blood 2014;123(20):3139-51.

35. Elf $S$, Abdelfattah NS, Chen E, Perales-Patón J, Rosen EA, Ko A, Peisker F, Florescu N, Giannini S, Wolach O, Morgan EA, Tothova Z, Losman J-A, Schneider RK, Al-Shahrour F, Mullally A. Mutant Calreticulin Requires Both Its Mutant C-terminus and the Thrombopoietin Receptor for Oncogenic Transformation. Cancer Discov 2016;6(4):368-81.

36. Marty C, Pecquet C, Nivarthi H, El-Khoury M, Chachoua I, Tulliez M, Villeval J-L, Raslova H, Kralovics R, Constantinescu SN, Plo I, Vainchenker W. Calreticulin mutants in mice induce an MPL- 
dependent thrombocytosis with frequent progression to myelofibrosis. Blood 2016;127(10):1317-24.

37. Shide K, Kameda T, Yamaji T, Sekine M, Inada N, Kamiunten A, Akizuk K, Nakamura K, Hidaka T, Kubuki Y, Shimoda H, Kitanaka A, Honda A, Sawaguchi A, Abe H, Miike T, Iwakiri H, Tahara Y, Sueta M, Hasuike S, Yamamoto S, Nagata K, Shimoda K. Calreticulin mutant mice develop essential thrombocythemia that is ameliorated by the JAK inhibitor ruxolitinib. Leukemia 2017;31(5):1136-44.

38. Li J, Prins D, Park HJ, Grinfeld J, Gonzalez-Arias C, Loughran S, Dovey OM, Klampfl T, Bennett C, Hamilton TL, Pask DC, Sneade R, Williams M, Aungier J, Ghevaert C, Vassiliou GS, Kent DG, Green AR. Mutant calreticulin knockin mice develop thrombocytosis and myelofibrosis without a stem cell self-renewal advantage. Blood 2018;131(6):64961.

39. Balligand T, Achouri Y, Pecquet C, Gaudray G, Colau D, Hug E, Rahmani Y, Stroobant V, Plo I, Vainchenker W, Kralovics R, Van den Eynde BJ, Defour J-P, Constantinescu SN. Knock-in of murine Calr del52 induces essential thrombocythemia with slow-rising dominance in mice and reveals key role of Calr exon 9 in cardiac development. Leukemia 2020;34(2):510-21

40. Benlabiod $C$, Cacemiro M da C, Nédélec $A$, Edmond V, Muller $D$, Rameau P, Touchard L, Gonin P, Constantinescu SN, Raslova H, Villeval J-L, Vainchenker W, Plo I, Marty C. Calreticulin del52 and ins5 knock-in mice recapitulate different myeloproliferative phenotypes observed in patients with MPN. Nat Commun 2020;11(1):4886.

41. Sangkhae V, Etheridge SL, Kaushansky K, Hitchcock IS. The thrombopoietin receptor, MPL, is critical for development of a JAK2V617Finduced myeloproliferative neoplasm. Blood 2014;124(26):3956-63.

42. Bhagwat N, Koppikar P, Keller M, Marubayashi S, Shank K, Rampal R, Qi J, Kleppe M, Patel HJ, Shah SK, Taldone T, Bradner JE, Chiosis G, Levine RL. Improved targeting of JAK2 leads to increased therapeutic efficacy in myeloproliferative neoplasms. Blood 2014;123(13):207583.

43. Ng AP, Kauppi M, Metcalf $D$, Hyland CD, Josefsson EC, Lebois $M$, Zhang J-G, Baldwin TM, Di Rago L, Hilton DJ, Alexander WS. Mpl expression on megakaryocytes and platelets is dispensable for thrombopoiesis but essential to prevent myeloproliferation. Proc Natl Acad Sci U S A 2014;111(16):5884-9.

44. Tefferi A, Lasho TL, Finke CM, Elala Y, Hanson CA, Ketterling RP, Gangat N, Pardanani A. Targeted deep sequencing in primary myelofibrosis. Blood Adv 2016;1(2):105-11.

45. Sashida G, Wang C, Tomioka T, Oshima M, Aoyama K, Kanai A, Mochizuki-Kashio M, Harada H, Shimoda K, Iwama A. The loss of Ezh2 drives the pathogenesis of myelofibrosis and sensitizes tumor-initiating cells to bromodomain inhibition. J Exp Med 2016;213(8):145977.

46. Shimizu T, Kubovcakova L, Nienhold R, Zmajkovic J, Meyer SC, HaoShen H, Geier F, Dirnhofer S, Guglielmelli P, Vannucchi AM, Feenstra JDM, Kralovics R, Orkin SH, Skoda RC. Loss of Ezh2 synergizes with JAK2-V617F in initiating myeloproliferative neoplasms and promoting myelofibrosis. J Exp Med 2016;213(8):1479-96.

47. Yang Y, Akada H, Nath D, Hutchison RE, Mohi G. Loss of Ezh2 cooperates with Jak2 $2617 \mathrm{~F}$ in the development of myelofibrosis in a mouse model of myeloproliferative neoplasm. Blood 2016;127(26):3410-23.

48. Chen E, Schneider RK, Breyfogle LJ, Rosen EA, Poveromo L, Elf S, Ko A, Brumme K, Levine R, Ebert BL, Mullally A. Distinct effects of concomitant Jak2V617F expression and Tet2 loss in mice promote disease progression in myeloproliferative neoplasms. Blood 2015;125(2):327-35.

49. Kameda T, Shide $K$, Yamaji T, Kamiunten A, Sekine $M$, Taniguchi $Y$ Hidaka T, Kubuki Y, Shimoda H, Marutsuka K, Sashida G, Aoyama K, Yoshimitsu M, Harada T, Abe H, Miike T, Iwakiri H, Tahara Y, Sueta M, Yamamoto S, Hasuike S, Nagata K, Iwama A, Kitanaka A, Shimoda K. Loss of TET2 has dual roles in murine myeloproliferative neoplasms: disease sustainer and disease accelerator. Blood 2015;125(2):304-15.

50. Jacquelin S, Straube J, Cooper L, Vu T, Song A, Bywater M, Baxter E, Heidecker M, Wackrow B, Porter A, Ling V, Green J, Austin R, Kazakoff S, Waddell N, Hesson LB, Pimanda JE, Stegelmann F, Bullinger L, Döhner K, Rampal RK, HeckI D, Hill GR, Lane SW. Jak2V617F and Dnmt3a loss cooperate to induce myelofibrosis through activated enhancer-driven inflammation. Blood 2018;132(26):2707-21.

51. Guo Y, Zhou Y, Yamatomo S, Yang H, Zhang P, Chen S, Nimer SD, Zhao ZJ, Xu M, Bai J, Yang F-C. ASXL1 alteration cooperates with
JAK2V617F to accelerate myelofibrosis. Leukemia 2019;33(5):128791.

52. Heckl D, Kowalczyk MS, Yudovich D, Belizaire R, Puram RV, McConkey ME, Thielke A, Aster JC, Regev A, Ebert BL. Generation of mouse models of myeloid malignancy with combinatorial genetic lesions using CRISPR-Cas9 genome editing. Nat Biotechnol 2014;32(9):9416.

53. Shide K, Kameda T, Kamiunten A, Oji A, Ozono Y, Sekine M, Honda A, Kitanaka A, Akizuki K, Tahira Y, Nakamura K, Hidaka T, Kubuki Y, Abe H, Miike T, Iwakiri H, Tahara Y, Sueta M, Hasuike S, Yamamoto S, Nagata K, Ikawa M, Shimoda K. Mice with Calr mutations homologous to human CALR mutations only exhibit mild thrombocytosis. Blood Cancer J 2019;9(4):42.

54. Bhatia S, Daschkey S, Lang F, Borkhardt A, Hauer J. Mouse models for pre-clinical drug testing in leukemia. Expert Opin Drug Discov. 2016;11(11):1081-91.

55. Koga Y, Ochiai A. Systematic Review of Patient-Derived Xenograft Models for Preclinical Studies of Anti-Cancer Drugs in Solid Tumors. Cells 2019;8(5):418.

56. Ishii T, Zhao Y, Sozer S, Shi J, Zhang W, Hoffman R, Xu M. Behavior of CD34+ cells isolated from patients with polycythemia vera in NOD/ SCID mice. Exp Hematol 2007;35(11):1633-40.

57. James C, Mazurier F, Dupont S, Chaligne R, Lamrissi-Garcia I, Tulliez M, Lippert E, Mahon F-X, Pasquet J-M, Etienne G, Delhommeau F, Giraudier S, Vainchenker W, de Verneuil H. The hematopoietic stem cell compartment of JAK2V617F-positive myeloproliferative disorders is a reflection of disease heterogeneity. Blood 2008;112(6):242938.

58. Reinisch A, Thomas D, Corces MR, Zhang X, Gratzinger D, Hong W-J, Schallmoser K, Strunk D, Majeti R. A Humanized Ossicle-niche Xenotransplantation Model Enables Improved Human Leukemic Engraftment. Nat Med 2016;22(7):812-21.

59. Rongvaux A, Willinger T, Martinek J, Strowig T, Gearty SV, Teichmann LL, Saito Y, Marches F, Halene S, Palucka AK, Manz MG, Flavell RA. Development and function of human innate immune cells in a humanized mouse model. Nat Biotechnol 2014;32(4):364-72.

60. Takenaka K, Prasolava TK, Wang JCY, Mortin-Toth SM, Khalouei $\mathrm{S}$, Gan OI, Dick JE, Danska JS. Polymorphism in Sirpa modulates engraftment of human hematopoietic stem cells. Nat Immunol 2007;8(12):1313-23.

61. Lysenko V, Wildner-Verhey van Wijk N, Zimmermann K, Weller M-C, Bühler M, Wildschut MHE, Schürch P, Fritz C, Wagner U, Calabresi L, Psaila B, Flavell RA, Vannucchi AM, Mead AJ, Wild PJ, Dirnhofer $S$, Manz MG, Theocharides APA. Enhanced engraftment of human myelofibrosis stem and progenitor cells in MISTRG mice. Blood Adv 2020;4(11):2477-88

62. Wernig G, Kharas MG, Okabe R, Moore SA, Leeman DS, Cullen DE, Gozo M, McDowell EP, Levine RL, Doukas J, Mak CC, Noronha G, Martin M, Ko YD, Lee BH, Soll RM, Tefferi A, Hood JD, Gilliland DG. Efficacy of TG101348, a selective JAK2 inhibitor, in treatment of a murine model of JAK2V617F-induced polycythemia vera. Cancer Cell 2008;13(4):311-20.

63. Meyer SC, Keller MD, Chiu S, Koppikar P, Guryanova OA, Rapaport F, Xu K, Manova K, Pankov D, O'Reilly RJ, Kleppe M, McKenney AS, Shih AH, Shank K, Ahn J, Papalexi E, Spitzer B, Socci N, Viale A, Mandon E, Ebel N, Andraos R, Rubert J, Dammassa E, Romanet V, Dölemeyer A, Zender M, Heinlein M, Rampal R, Weinberg RS, Hoffman R, Sellers WR, Hofmann F, Murakami M, Baffert F, Gaul C, Radimerski T, Levine RL. CHZ868, a Type II JAK2 Inhibitor, Reverses Type I JAK Inhibitor Persistence and Demonstrates Efficacy in Myeloproliferative Neoplasms. Cancer Cell 2015;28(1):15-28.

64. Stivala S, Codilupi T, Brkic S, Baerenwaldt A, Ghosh N, Hao-Shen $\mathrm{H}_{\text {, }}$ Dirnhofer S, Dettmer MS, Simillion C, Kaufmann BA, Chiu S, Keller M, Kleppe M, Hilpert M, Buser AS, Passweg JR, Radimerski T, Skoda RC, Levine RL, Meyer SC. Targeting compensatory MEK/ERK activation increases JAK inhibitor efficacy in myeloproliferative neoplasms. J Clin Invest 2019;129(4):1596-611.

65. Shen FW, Saga Y, Litman G, Freeman G, Tung JS, Cantor H, Boyse EA. Cloning of Ly-5 CDNA. Proc Natl Acad Sci U S A. 1985;82(21):7360-63.

66. Akada H, Akada S, Gajra A, Bair A, Graziano S, Hutchison RE, Mohi G. Efficacy of vorinostat in a murine model of polycythemia vera. Blood 2012;119(16):3779-89.

67. Waibel M, Solomon VS, Knight DA, Ralli RA, Kim S-K, Banks K-M, Vidacs E, Virely C, Sia KCS, Bracken LS, Collins-Underwood R, 
Drenberg C, Ramsey LB, Meyer SC, Takiguchi M, Dickins RA, Levine R, Ghysdael J, Dawson MA, Lock RB, Mullighan CG, Johnstone RW. Combined targeting of JAK2 and $\mathrm{BCl}-2 / \mathrm{BCl}-\mathrm{xL}$ to cure mutant JAK2 driven malignancies and overcome acquired resistance to JAK2 inhibitors. Cell Rep 2013;5(4):1047-59.

68. Mullally A, Bruedigam C, Poveromo L, Heidel FH, Purdon A, Vu T, Austin R, Heckl D, Breyfogle LJ, Kuhn CP, Kalaitzidis D, Armstrong SA, Williams DA, Hill GR, Ebert BL, Lane SW. Depletion of Jak2V617F myeloproliferative neoplasm-propagating stem cells by interferon-a in a murine model of polycythemia vera. Blood 2013;121(18):3692702.

69. Austin RJ, Straube J, Bruedigam C, Pali G, Jacquelin S, Vu T, Green J, Gräsel J, Lansink L, Cooper L, Lee S-J, Chen N-T, Lee C-W, Haque A, Heidel FH, D'Andrea R, Hill GR, Mullally A, Milsom MD, Bywater M, Lane SW. Distinct effects of ruxolitinib and interferon-alpha on murine JAK2V617F myeloproliferative neoplasm hematopoietic stem cell populations. Leukemia 2020;34(4):1075-89.

70. Hasan S, Lacout C, Marty C, Cuingnet M, Solary E, Vainchenker W, Villeval J-L. JAK2V617F expression in mice amplifies early hematopoietic cells and gives them a competitive advantage that is hampered by IFNa. Blood 2013;122(8):1464-77.

71. Chisolm DA, Cheng W, Colburn SA, Silva-Sanchez A, Meza-Perez $S$, Randall TD, Weinmann AS. Defining Genetic Variation in Widely Used Congenic and Backcrossed Mouse Models Reveals Varied
Regulation of Genes Important for Immune Responses. Immunity 2019;51(1):155-68.

72. Basu S, Ray A, Dittel BN. Differential representation of B cell subsets in mixed bone marrow chimera mice due to expression of allelic variants of CD45 (CD45.1/CD45.2). J Immunol Methods 2013;396(12):163-7.

73. Jafri S, Moore SD, Morrell NW, Ormiston ML. A sex-specific reconstitution bias in the competitive CD45.1/CD45.2 congenic bone marrow transplant model. Sci Rep 2017;7(1):3495.

74. Jang Y, Gerbec ZJ, Won T, Choi B, Podsiad A, B Moore B, Malarkannan S, Laouar Y. Cutting Edge: Check Your Mice-A Point Mutation in the Ncr1 Locus Identified in CD45.1 Congenic Mice with Consequences in Mouse Susceptibility to Infection. J Immunol 2018;200(6):1982-87.

75. Mercier FE, Sykes DB, Scadden DT. Single Targeted Exon Mutation Creates a True Congenic Mouse for Competitive Hematopoietic Stem Cell Transplantation: The C57BL/6-CD45.1(STEM) Mouse. Stem Cell Reports 2016;6(6):985-92.

76. Schaefer BC, Schaefer ML, Kappler JW, Marrack P, Kedl RM. Observation of antigen-dependent CD8+ T-cell/ dendritic cell interactions in vivo. Cell Immunol 2001;214(2):110-22.

77. Dagher T, Maslah N, Edmond V, Cassinat B, Vainchenker W, Giraudier S, Pasquier F, Verger E, Niwa-Kawakita M, Lallemand-Breitenbach V, Plo I, Kiladjian JJ, Villeval JL, de Thé H. JAK2V617F myeloproliferative neoplasm eradication by a novel interferon/arsenic therapy involves PML. J Exp Med 2021;218(2):e20201268. 